\title{
Peran Keluarga dalam Pendidikan Anak pada Masa Pandemi Covid-19
}

\author{
Frans Pantan ${ }^{1}$, Priskila Issak Benyamin ${ }^{2}$ \\ ${ }^{1,2}$ Sekolah Tinggi Teologi Bethel Indonesia, Jakarta \\ Ifranspantan@gmail.com, ${ }^{2}$ priskilaissakbenyamin@gmail.com
}

DOI: https://doi.org $/ 10.47167 /$ hharis.V3i1.43

\begin{abstract}
The occurrence of the Covid-19 pandemic virus caused the family's role in children's education to become increasingly strategic. Until now not many studies have examined the role of families in children's education. This study aims to analyze deeply the role of the family in children's education. This research is a qualitative ethnographic study. Data were collected using in-depth interview techniques and participatory observation. The data source is the primary source (both parents and mothers) approached by purposive technique and continued with a snowball. The data is then validated by source triangulation techniques and methods. The collected data is then analyzed using the interactive data analysis technique of the Miles and Huberman model, which consists of the stages of data collection, data reduction, data display, and conclusion. The results showed that there were 7 main roles of the family in children's education, namely: (1) The function of the faith; (2) Educational functions; (3) The function of socialization; (4) Protection or protection functions; (5) Affection function; (6) Economic functions; (7) Recreational functions. After going through a process of discussion with relevant theories and research results, it was found that the seven roles holistically had never been raised together before. This is a new finding from this research, where this finding will certainly be different from the findings if there is no pandemic, or if disasters occur in other forms.
\end{abstract}

Keywords: Covid-19; Christian family; children's education; Christian education

\begin{abstract}
Abstrak
Terjadinya pandemi virus covid-19 menyebabkan peran keluarga dalam pendidikan anak menjadi semakin strategis. Hingga saat ini belum banyak penelitian yang mengkaji peran keluarga dalam pendidikan anak. Penelitian ini bertujuan untuk menganalisis secara mendalam mengenai peran keluarga dalam pendidikan anak. Penelitian ini merupakan penelitian kualitatif etnografi. Data dikumpulkan dengan menggunakan teknik wawancara mendalam dan observasi partisipatif. Sumber data adalah sumber primer (orangtua baik ayah maupun ibu) yang didekati dengan teknik purposive dan dilanjutkan dengan snowball. Data selanjutnya divalidasi dengan teknik triangulasi sumber dan metode. Data yang terkumpul kemudian dianalisis dengan teknik analisis data interaktif model Miles and Huberman, yang terdiri dari tahap data collection, data reduction, data display, dan conclution. Hasil penelitian menunjukkan bahwa terdapat 7 peran utama keluarga dalam pendidikan anak, yaitu: (1) Fungsi keimanan; (2) Fungsi edukatif; (3) Fungsi sosialisasi; (4) Fungsi proteksi atau perlindungan; (5) Fungsi afeksi; (6) Fungsi ekonomi; (7) Fungsi rekreasi. Setelah melalui proses pembahasan dengan teori-teori dan hasil-hasil penelitian yang relevan, ditemukan bahwa ketujuh peran tersebut secara holistik belum pernah diangkat secara bersama-sama sebelumnya. Hal inilah yang menjadi temuan baru dari penelitian ini, di mana temuan ini tentu akan berbeda dengan temuan jika tidak terjadi pandemic, maupun jika terjadi bencana dalam bentuk-bentuk yang lain.
\end{abstract}

Kata kunci: Covid-19; keluarga Kristen; pendidikan anak; pendidikan Kristen 


\section{PENDAHULUAN}

Pendidikan merupakan suatu proses yang berlangsung seumur hidup (long life education) pada diri manusia, dimulai sejak dari dalam rahim sampai pada ambang kubur (from womb to tomb). Hal inilah yang dikemukakan oleh Ki Hadjar Dewantara. ${ }^{1}$ Tentu, ketika berbicara mengenai pendidikan, terlebih dahulu harus dipahami adanya beberapa unsur penting yang saling terkait secara erat antara satu sama lainnya, yakni: pendidik, peserta didik, sarana prasarana dan tempat berlangsungnya proses pendidikan, kurikulum, buku-buku, dan masih banyak lagi alat bantu lainnya. Apabila salah satu di antara unsur yang disebutkan tersebut diabaikan maka tentu dapat dipastikan pendidikan tidak akan berlangsung secara baik dan optimal.

Proses pendidikan manusia, memuat unsur yang bersifat utama dan pertama (dapat disebut unsur primer). Unsur primer yang dimaksudkan tersebut mencakup usia, tempat berlangsungnya proses pendidikan dan siapa penanggung jawabnya dan pelaksana utamanya. Usia belajar yang paling krusial bagi manusia bukan pada saat mereka belajar di universitas melainkan pada usia $1 \mathrm{~s} / \mathrm{d} 12$ tahun. Dapat dikatakan bahwa pendidikan yang diterima manusia pada rentang usia 1 s/d 12 tahun (usia anak-anak) merupakan dasar dan/atau fondasi yang sangat menentukan kesiapan seseorang, khususnya anak-anak untuk mengikuti pendidikan selanjutnya. Erikson berpendapat bahwa anak usia 0-2 tahun mulai terbentuk harapan dalam diri anak, 2-4 tahun mulai berkembang prakarsa atau kehendak, 46 tahun mulai muncul keinginan untuk menetapkan tujuan, dan 6-12 tahun mulai pengembangan kompetensi dalam diri anak. ${ }^{2}$

Benar bahwa usia di atas disebut sebagai usia sekolah, khususnya mulai pada usia 4 tahun. Tetapi harus dipahami bahwa tempat yang utama dan pertama berlangsungnya proses pendidikan dalam rangka membentuk empat aspek keutamaan pendidikan bagi anak sesuai dengan usianya adalah di rumah dan di dalam keluarga. Hal ini karena di rumahlah pertama kali anak-anak diajarkan dan diperkenalkan berbagai hal mengenai nilai-nilai dasar kehidupan, termasuk harapan, kehendak, tujuan dan kompetensi. Dalam pendidikan di rumah ini, yang menjadi penanggung jawab utama adalah orang tua. Karena itu, pendidik utama dan pertama di rumah atau di dalam keluarga adalah orang tua.

Didasari dengan apa yang dikemukakan di atas, dapat dinyatakan bahwa sudah tidak relevan lagi untuk memperdebatkan di mana dan kapan dimulainya pendidikan yang efektif bagi manusia kecuali menyepakati bersama bahwa di rumah atau di dalam keluarga adalah tempatnya. Di samping itu, usia yang paling krusial adalah dari usia satu (1) sampai dengan dua belas (12) tahun. Keluarga merupakan tempat yang paling awal dan efektif untuk menjalankan dan/atau melaksanakan pendidikan bagi seluruh anggotanya, khususnya bagi anak-anak pada rentang usia di atas. Di rumah atau di dalam keluargalah pertama kali diajarkan tentang pentingnya beriman kepada Tuhan, kejujuran, semangat, keinginan untuk menjadi yang terbaik, bersosialisasi, memimpin, berpolitik dan kemampuan-kemampuan dasar lainnya.

\footnotetext{
${ }^{1}$ Yamin, M, Menggugat Pendidikan Indonesia: Belajar dari Paulo Freire dan Ki Hajar Dewantara. (Yogyakarta: Ar Ruzz Media, 2009).

${ }^{2}$ Sijabat, B. S, Membesarkan Anak Dengan Kreatif (Yogyakarta: Andi Offset, 2008)
} 
Apabila hal-hal yang perlu diajarkan gagal diajarkan di dalam rumah atau di dalam keluarga maka dapat dipastikan akan sulit sekali bagi institusi-institusi lain seperti sekolah untuk memperbaiki kegagalan-kegagalan tersebut di kemudian hari. Tentu, kondisi seperti itu merupakan suatu kerugian besar untuk masa depan keluarga dan bangsa. Dengan demikian, jelas bahwa keluarga menempati tempat yang sangat sentral dan strategis dalam mempersiapkan masa depan warga masyarakat keluarga dan bangsa yang berkualitas unggul, khususnya dalam menjalani tugas kehidupan di era postmodern.

Sejak adanya pandemic Covid-19 pembelajaran formal yang sebelumnya dilakukan secara konvensional di sekolah menjadi berubah karena harus dilaksanakan di rumah. Pembelajaran yang dilakukan di rumah (study from home) ikut menambah beban tanggung jawab bagi orangtua atau keluarga untuk semakin terlibat dalam pendidikan anaknya. Orangtua perlu mengetahui metode pembelajaran yang tepat bagi anaknya di masa pandemi Covid-19. ${ }^{3}$ Perubahan kultur budaya dari yang semula pembelajaran dilakukan melalui pertemuan anak dengan guru secara langsung, kini berubah di mana anak tidak bertemu guru secara langsung. Dalam proses yang baru inilah, peran keluarga dalam pendidikan anak menjadi hal yang penting. Perubahan dalam pendidikan perlu disikapi dengan baik. Kemampuan beradaptasi terhadap perubahan menjadi kunci keberhasilan anak dalam pendidikannya. Untuk itulah, maka orangtua perlu melakukan pendidikan sedemikian rupa, sehingga anak dapat memiliki kemampuan penyesuaian diri yang baik. Supaya dapat mengajarkan kemampuan penyesuaian diri, maka orangtua telebih dahulu perlu memiliki kemampuan penyesuaian diri yang baik.

Respon terhadap situasi Pandemi Covid-19 ini telah menghasilkan berbagai kajian terkait pelayanan gerejawi, seperti yang diungkapkan Abdon Amtiran, bahwa pandemi ini telah memicu munculnya beragam mazhab teologi sebagai respon teologis. ${ }^{4}$ Susanto Dwiraharjo mengusung isu gereja digital sebagai respon terhadap dibatasinya pertemuan secara fisik di gereja selama masa pandemi. ${ }^{5}$ Ide berbeda ditawarkan oleh Irwan Widjaja yang melihat kesempatan dibangkitkannya lagi gerakan gereja rumah seperti yang pernah ada di masa para rasul. ${ }^{6}$ Ide kelompok sel virtual juga dicetuskan demi mempertahankan keberlangsungan pelayanan kelompok sel di tengah pembatasan pertemuan fisik. ${ }^{7}$ Kajian tersebut mencoba memberikan solusi pada masyarakat Kristen untuk merespon secara baik dan benar situasi yang diakibatkan oleh pandemi Covid-19 ini. Bukan hanya tentang pelayanan gerejawi, isu pendidikan menjadi bagian yang penting diteliti terkait pandemi ini.

${ }^{3}$ Prislika issak Benyamin, Yogi Mahendra, and Donald Samuel Slamet Santosa, "Metode Pembelajaran Untuk Meningkatkan Prestasi Belajar Siswa Pada Mata Pelajaran Pendidikan Agama Kristen: Studi Meta Analisis," SOTIRIA (Jurnal Teologi dan Pelayanan Kristiani) 3, no. 1 (2020): 25-35,

http://sttpaulusmedan.ac.id/e-journal/index.php/sotiria/article/view/17.

${ }^{4}$ Abdon Amtiran, "Pandemi Covid-19 Dan Implikasinya Terhadap Polarisasi Mazhab Teologi Di Indonesia," MAGNUM OPUS: Jurnal Teologi dan Kepemimpinan Kristen 1, no. 2 (2020): 64-71.

${ }^{5}$ Susanto Dwiraharjo, "Konstruksi Teologis Gereja Digital: Sebuah Refleksi Biblis Ibadah Online Di Masa Pandemi Covid-19,” EPIGRAPHE: Jurnal Teologi dan Pelayanan Kristiani 4, no. 1 (2020): 1-17.

${ }^{6}$ Fransiskus Irwan Widjaja et al., "Menstimulasi Praktik Gereja Rumah Di Tengah Pandemi Covid-19," Kurios (Jurnal Teologi dan Pendidikan Agama Kristen) 6, no. 1 (2020): 127-139, http://www.sttpb.ac.id/ejournal/index.php/kurios/article/view/166.

${ }^{7}$ Irwanto Berutu and Harls Evan R Siahaan, "Menerapkan Kelompok Sel Virtual Di Masa Pandemi Covid-19," SOTIRIA (Jurnal Theologia dan Pendidikan Agama Kristen) 3, no. 1 (2020): 53-65. 
Pada sisi pendidikan Kristen, Asmat Purba melihat pentingnya keluarga memberi-kan pendidikan kepada anak demi menyikapi situasi yang sedang terjadi. ${ }^{8}$ Kajian yang dilakukan Purba bertitik tolak pada tanggung jawab orang tua dalam keluarga untuk memberikan edukasi terkait situasi yang mengakibatkan banyak hal berubah dalam kebiasaan dan pola hidup anak. Penelitian ini lebih menekankan bagaimana tetap mempertahankan terjadinya proses pendidikan kepada anak pada masa pandemi. Penelitian ini bertujuan agar orang tua dapat melihat bagaimana strategi perubahan dalam pendidikan anak di rumah dilakukan. Orang tua mendapatkan arahan tentang cara mendidik anak pada masa pandemi Covid-19 saat ini. Untuk itulah maka diharapkan orang tua dapat melakukan adaptasi atau penyesuaian diri dengan cara baru untuk mendidik anaknya di rumah.

\section{METODE PENELITIAN}

Penelitian ini merupakan penelitian kualitatif etnografi. Penelitian kualitatif merupakan penelitian yang digunakan untuk menyelidiki, menemukan, menggambarkan, dan menjelaskan kualitas atau keistimewaan dari pengaruh sosial yang tidak dapat dijelaskan, diukur atau digambarkan melalui pendekatan kuantitatif ${ }^{9}$. Sebagaimana dikemukakan oleh Saryono tersebut, penelitian ini hendak menganalisis keistimewaan dari pengaruh sosial tertentu (dalam hal ini keluarga) kepada pembentukan anak melalui proses pendidikan. Selanjutnya, karena analisis perlu dilakukan secara mendalam, maka penelitian ini tidak menggunakan pendekatan kuantitatif.

Penelitian etnografi merupakan kegiatan pengumpulan bahan keterangan atau data yang dilakukan secara sistematik mengenai cara hidup serta berbagai aktivitas sosial yang berkaitan dengan itu dan berbagai benda kebudayaan dari suatu masyarakat, yang berdasarkan bahan-bahan keterangan tersebut dibuat deskripsi mengenai kebudayaan masyarakat tersebut ${ }^{10}$. Berdasarkan penjelasan tersebut, fokus yang dikaji dalam penelitian ini adalah budaya yang ada dalam keluarga Indonesia, khususnya terkait dengan budaya dalam kaitannya dengan memberikan pendidikan bagi anak. Pendidikan yang dimaksud adalah pendidikan yang dilaksanakan dalam lingkungan keluarga, dan bukan dukungan keluarga dalam kaitannya dengan pendidikan formal maupun nonformal. Hasil kajian akan menghasilkan data yang merupakan deskripsi mengenai budaya orang tua dalam mendidik anak di lingkungan keluarga. Peran keluarga (orang tua) menjadi fokus luaran yang dihasilkan dari penelitian ini, sehingga hal ini menjadi satuan analisis penelitian.

Data yang akan dikumpulkan berbentuk kualitatif. Data dikumpulkan dengan teknik wawancara mendalam dan observasi partisipatif kepada sumber-sumber data. Data dikumpulkan dengan instrumen pedoman wawancara dan pedoman observasi yang bersifat terbuka, dan dapat berkembang sesuai dengan jawaban dari informan penelitian. Data berasal dari sumber primer, yaitu orangtua dan anak yang merupakan satuan pengamatan

${ }^{8}$ Asmat Purba, "Tanggung Jawab Orang Tua Kristen Dalam Mendidikan Anak Menyikapi Pandemi Covid-19,” EPIGRAPHE: Jurnal Teologi dan Pelayanan Kristiani 4, no. 1 (2020): 86-100, http://www.stttorsina.ac.id/jurnal/index.php/epigraphe/article/view/148.

${ }^{9}$ Saryono. 2010. Metode Penelitian Kualitatif. Bandung: Alfabeta

${ }^{10}$ Endraswara, S. 2006. Metode, Teori, Teknik Penelitian Kebudayaan: Ideologi, Epistemologi, dan Aplikasi. Yogyakarta: Pustaka Widyatama 
penelitian ini. Sumber data dipilih secara purposive pada mulanya, dan berkembang sesuai dengan pola snowball sampling.

Data dikumpulkan pada masa Pandemi Covid-19, yaitu pada bulan April hingga Mei 2020. Pengumpulan data dilakukan dengan memperhatikan protokol kesehatan yang berla$\mathrm{ku}$, tanpa mengurangi keilmiahan proses pengumpulan data, sehingga data yang terkumpul tetap dapat dipertanggung jawabkan keilmiahannya. Data yang terkumpul kemudian divalidasi dengan teknik triangulasi. Triangulasi yang dilakukan dalam penelitian ini meliputi triangulasi teknik dan triangulasi sumber. Pada triangulasi teknik, data yang dihasilkan dari teknik wawancara dikroscek dengan data yang dihasilkan dari teknik observasi. Sedangkan pada triangulasi sumber, data yang diperoleh dari sumber yang satu dikroscek dengan data dari sumber yang lain. Hanya data-data yang terkonfirmasi valid saja yang selanjutnya diakui sebagai data penelitian ini.

Data dianalisis dengan teknik analisis data interaktif model Miles and Huberman ${ }^{11}$. Dalam teknik ini, terdapat 4 tahap analisis, yaitu tahap data collection, data reduction, data display, dan conclution. Data collection merupakan awal proses tahap pengumpulan data. Data yang dikumpulkan kemudian divalidasi dengan triangulasi. Data-data yang tidak relevan dengan penelitain dan data yang tidak tervalidasi kemudian direduksi (data reduction), dan data yang tervalidasi kemudian ditayangkan (data display). Akhirnya, data yang terdisplay disimpulkan dalam tahap conclution.

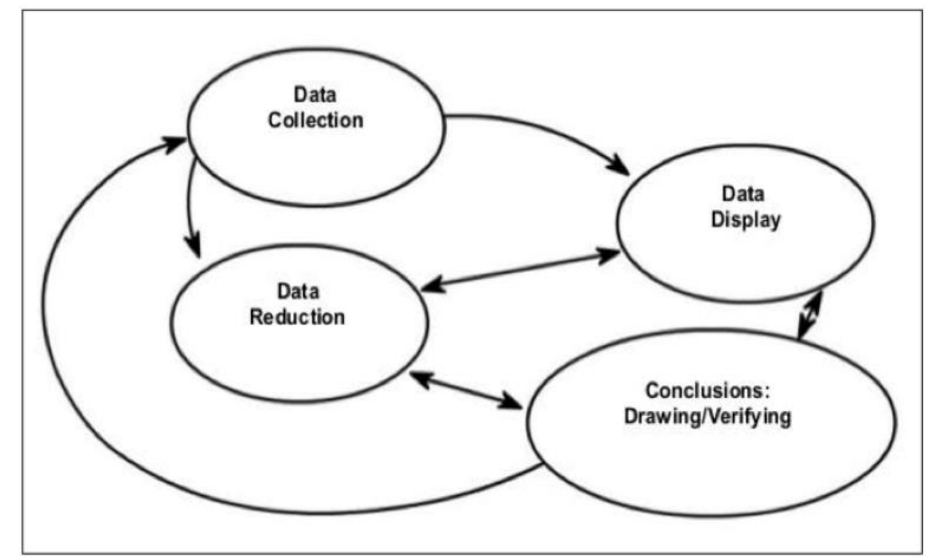

Gambar Teknik Analisis Data Interaktif Model Miles and Hubberman

\section{HASIL DAN PEMBAHASAN}

Pandemi Covid-19 berdampak pada berbagai hal, termasuk perubahan dalam pola pendidikan formal. Perubahan-perubahan tersebut berdampak pada kesulitan yang dialami siswa ketika menjalani pola pembelajaran yang baru. Kesulitan terjadi salah satunya akibat dari tidak dimilikinya kemampuan adaptasi yang baik dalam diri siswa. Kemampuankemampuan semacam ini perlu dikembangkan sejak dari keluarga. Untuk itulah peran keluarga menjadi lebih jelas dengan adanya pandemic covid-19 ini. Keluarga yang tidak

${ }^{11}$ Miles, M. B., Huberman, A. M., Saldana, J. Qualitative Data Analysis: A Methods Sourcebook (Sage Publication, 2014) 
menjalankan perannya dengan baik dapat berdampak pada buruknya kemampuan adaptasi anak, dan dampak akhirnya adalah kesulitan dalam menerima perubahan yang terjadi.

Penelitian telah dilakukan dengan teknis yang telah direncanakan dalam penelitian ini. Pada bagian hasil penelitian dan pembahasan ini, disajikan mengenai data display yang diperoleh. Dengan demikian, data yang disajikan dalam penelitian ini telah melalui tahap data collection dan data reduction. Sedangkan, konklusi dari penelitian ini akan dijelaskan pada bagian selanjutnya. Untuk mempermudah sajian, maka pembahasan hasil penelitian disajikan secara terintegrasi dengan hasil penelitian. Setiap fungsi atau peran keluarga yang merupakan hasil dari penelitian akan langsung dikaitkan dengan teori sebelumnya sebagai bentuk pembahasan hasil penelitian.

Terjadinya pandemi Covid-19 dimungkinkan berdampak pada perbedaan hasil penelitian apabila dibandingkan dengan bila penelitian ini dilakukan sebelum adanya pandemi. Para informan cenderung bersemangat ketika wawancara maupun observasi dilakukan. Banyak data yang berhasil diperoleh, dan kemudian di sintesis dalam penelitian ini. Berdasarkan penelitian yang telah dilakukan, terdapat 7 fungsi atau peran keluarga dalam pendidikan anak. Ketujuh fungsi tersebut adalah (1) Fungsi keimanan; (2) Fungsi edukatif; (3) Fungsi sosialisasi; (4) Fungsi proteksi atau perlindungan; (5) Fungsi afeksi; (6) Fungsi ekonomi; (7) Fungsi rekreasi. Berikut jabaran penjelasan dan pembahasan dari ketujuh fungsi tersebut.

Pertama, fungsi keimanan. Seperti yang sudah dikemukakan sebelumnya, pendidikan iman itu dimulai di rumah atau di dalam keluarga. Orangtua sebagai pendidik perlu berhikmat untuk menuntun anak-anak menuju pencapaian hidup berkualitas ${ }^{12}$. Pandemi Covid-19 membuat anak lebih banyak di rumah, sehingga kehidupan keimanan anak banyak bergantung pada peran pendidikan dalam keluarga. Sekolah tidak lagi menjalankan aktifitas rutinnya, yang pada pada hari diawali dengan doa, dan ditutup pula dengan doa pada siang hari. Selain itu, gereja juga tidak banyak berperan dalam masa pandemic akibat dilaksanakannya ibadah secara daring. Untuk itulah maka keluarga perlu menjalankan pendidikan bagi anak untuk mengembangkan keimanannya. Temuan ini sejalan dengan teori dari Fowler bahwa salah satu tahapan iman yang harus dilalui atau dialami setiap orang adalah meniru iman orang yang sudah lebih dewasa ${ }^{13}$. Tahapan dan proses seperti itu dimulai di dalam keluarga pada usia anak-anak. Di mana iman anak-anak sangat tergantung pada iman yang dilihat pada orang tua dan orang dewasa lainnya yang ada di sekitarnya setiap saat. Itulah sebabnya orang tua di dalam keluarga harus menjadi teladan iman yang konsisten bagi anak-anaknya. Dengan kata lain keseluruhan realitas kehidupan yang ditampilkan orangtua di depan anak-anak (tutur kata, sikap dan perbuatan) harus mencerminkan karakter keimanannya.

Kedua, fungsi edukatif. Seperti yang sudah dikemukakan pada bagian pengantar di atas bahwa keluarga adalah tempat utama dan pertama berlangsungnya proses pendidikan

\footnotetext{
${ }^{12}$ Harls Evan Rianto Siahaan, "Hikmat Sebagai Implikasi Pendidikan Kristiani Dalam Keluarga: Refleksi 1 Raja-Raja 3:1-15," DUNAMIS: Jurnal Teologi dan Pendidikan Kristiani, Vol 1, no. 1 (2016): 1530, www.sttintheos.ac.id/e-journal/index.php/dunamis.

${ }^{13}$ Fowler, J. W. 1995. Stages of Faith: The Psychology of Human Development. Harper Collins
} 
paling dasar bagi manusia. Hal ini sejalan dengan konsep Tripusat Pendidikan dari Ki Hajar Dewantara $^{14}$ yang kemudian melahirkan konsep pendidikan formal, nonformal, dan informal. Dalam konsep tersebut, keluarga jelas merupakan lingkungan pertama bagi pendidikan anak. Sesuai dengan penelitian dari Susanta, anak berhak mendapatkan pendidikan dari keluarga mereka ${ }^{15}$. Karena itu, keluarga harus memainkan peranannya sebagai alat dan/atau sarana yang efektif untuk pendidikan anak. Prinsip dan kondisi seperti itu harus mulai ditekankan pada anak-anak di dalam keluarga dan/atau di rumah secara jelas dan tegas. Hal itu sangat dasar dan menentukan, dan apabila dilakukan dengan baik, maka dapat dipastikan mereka adalah generasi penerus keluarga, masyarakat dan bangsa yang sangat luar biasa. Pada masa pandemic covid-19, peran keluarga menjadi lebih besar, akibat dari dilaksanakannya pendidikan formal dan nonformal dari rumah. Dalam menjalankan hal ini, keluarga atau orangtua perlu memberikan bimbingan atau pendampingan kepada anak, supaya bisa mengikuti pembelajaran dalam pendidikan formal dan nonformal dengan baik.

Ketiga, fungsi sosialisasi. Salah satu hakikat dasar manusia adalah ia diciptakan sebagai makhluk sosial. Fakta kebenaran seperti itu mau menegaskan bahwa manusia tidak akan bisa hidup dan bermakna optimal tanpa memiliki relasi sosial yang baik dengan sesamanya serta makhluk ciptaan lainnya. Pemahaman seperti itu seharusnya menyadarkan dan sekaligus mendorong keluarga secara khusus para orang tua untuk mendidik dan membimbing anak-anak di dalam rumah agar mampu dan terampil beradaptasi dengan kehidupan sosialnya, yakni masyarakat dan lingkungannya. Sesungguhnya, pendidikan sosialisasi kepada anak-anak dapat dipastikan efektif menghantar mereka untuk diterima kehadirannya dengan baik ketika mereka sudah mulai masuk ke dalam masyarakat luas. Bukan hanya itu, mereka pun dipastikan mampu memainkan perannya dengan baik.

Penelitian yang dilakukan oleh Sihotang dan Santosa menunjukkan bahwa anak yang memiliki berbagai pengalaman berorganisasi lebih siap dalam menghadapi dunia kerja dibanding yang tidak memiliki pengalaman ${ }^{16}$. Penelitian dari Sihotang dan Santosa ini tentu sejalan dengan temuan penelitian ini, di mana kemampuan sosialisasi dapat diwujudkan dengan aktifnya anak dalam organisasi. Meski demikian, secara teknis perlu adanya kegiatan sosialisasi yang dilakukan secara berbeda guna menjawab kebutuhan untuk memutus mata rantai Covid-19 saat ini. Kemampuan anak dalam hal penyesuaian diri, dan kemampuan adaptasi merupakan bagian dalam fungsi sosialisasi ini. Perubahan-perubahan yang terjadi dalam pendidikan maupun kehidupan merupakan hal yang perlu disikapi sebagai akibat terjadinya pandemic Covid-19. Untuk itulah maka keluarga perlu menyiapkan kemampuan sosialisasi dalam diri anak, sehingga anak dapat melakukan penyesuaian dengan perubahan yang terjadi. Pada masa pandemic Covid-19 saat ini, proses sosialisasi sangat dibatasi oleh pemerintah dan peraturan-peraturan yang ada. Apabila konsep social distancing diajarkan pada anak saat ini, maka dimungkinkan bahwa anak

\footnotetext{
${ }^{14}$ Darmadi, H. Pengantar Pendidikan Era Globalisasi: Konsep Dasar, Teori, Strategi dan Implementasi dalam Pendidikan Globalisasi. An1mage, 2019.

${ }^{15}$ Yohanes Krismantyo Susanta, "Tradisi Pendidikan Iman Anak Dalam Perjanjian Lama," BIA': Jurnal Teologi dan Pendidikan Kristen Kontekstual 2, no. 2 (2019): 139-150.

${ }^{16}$ Sihotang, F. H., Santosa, D. S. S. "Pengaruh Prestasi Belajar, Penguasaan Teknologi Informasi dan Pengalaman Organisasi Terhadap Kesiapan Kerja,” Jurnal Ecodunamika, 2 (1), 2019
} 
akan tertanam konsep untuk menjauhi orang lain (misalnya tidak mau diajak jabat tangan atau menjaga jarak fisik dengan orang lain). Hal ini menimbulkan kesalahan dalam konsep yang ditanamkan kepada anak. Dikhawatirkan, hingga pandemic berakhir, anak akan tertanam dalam benaknya bahwa dirinya harus menjaga jarak dengan pihak lain. Untuk itulah maka keluarga perlu memberikan pemahaman bahwa social distancing hanya dilakukan sementara waktu, hingga pandemic Covid-19 berakhir.

Keempat, fungsi proteksi atau perlindungan. Hadirnya manusia baru di atas muka bumi ini (kelahiran anak di dalam keluarga) ternyata sudah disambut dan dikuasai oleh berbagai ketakutan. Misalnya, begitu seorang anak lahir maka ia pasti menangis. Hal ini merupakan akibat karena dirinya mengalami perasaan terancam. Menyadari kondisi seperti itu, maka salah satu tugas penting keluarga dan orangtua terhadap anak-anak adalah memastikan bahwa anak-anak mereka memperoleh pengalaman rasa aman, nyaman, damai dan tenteram di rumah. Pengalaman seperti itu hanya bisa terjadi ketika orang tua hadir secara penuh memberikan proteksi atau perlindungan bagi anak-anak. Terlebih dalam masa pandemi Covid-19, proteksi terhadap anak menjadi penting untuk menjaga anak tetap dalam kondisi sehat, sehingga terhindar dari wabah Covid-19. Dengan kata lain, ketika orang tua memberikan proteksi yang baik kepada anak-anaknya, diyakini sangat efektif untuk menumbuhkan semangat dan optimisme tinggi bagi anak-anak dalam rangka mewujudkan diri menjadi pribadi yang berkarakter baik serta berprestasi optimal sesuai dengan bakat dasar yang dimilikinya. Salah satu karakter yang dimaksud adalah kemandirian sosial ${ }^{17}$. Meski demikian, kondisi pandemi Covid-19 yang terjadi saat ini memungkinkan orangtua menjadi over protective kepada anak. Hal ini dapat berdampak pada perasaan anak yang akan lebih manja, akibat dari perlindungan yang berlebihan dari orangtuanya. Untuk itulah maka sebelum anak menjadi termind set bahwa keselamatannya menjadi tanggung jawab mutlak orangtua, orangtua perlu memberikan pemahaman atau menanamkan konsep yang benar ke dalam diri anak. Ketika pandemi berakhir, maka intensitas orangtua untuk melakukan proteksi kepada anak dapat disesuaikan kembali, dan tidak perlu memberikan proteksi yang berlebihan. Dengan demikian anak mampu menyadari bahwa proteksi yang berlebihan saat ini dilakukan karena sedang terjadinya pandemi Covid-19.

Kelima, fungsi afeksi. Tempat yang paling efektif dan yang pertama untuk belajar menumbuhkan serta mengembangkan rasa cinta dan kasih sayang terhadap sesama adalah di dalam keluarga atau di rumah. Hal ini penting dalam rangka membangun karakter anak ${ }^{18}$. Itulah sebabnya, orang tua di dalam keluarga harus memastikan bahwa rumahnya dapat menjadi taman belajar yang menyenangkan, khususnya dalam merefleksikan rasa cinta dan kasih sayang yang tulus antara suami dengan isteri, antara orang tua dengan anak-anak, antara anak-anak dan bahkan di antara seluruh anggota keluarga. Kalau pengalaman seperti itu sudah terbentuk di rumah atau di dalam keluarga maka dapat dipastikan pengalaman

\footnotetext{
${ }^{17}$ Machmudah, Supriyono, Rasyad, A, "Perilaku Orangtua Menumbuhkan Kemandirian Sosial di Sekolah Melalui Proteksi Orangtua, Kelekatan Ibu dan Pola Tidur Anak," Jurnal Pendidikan: Teori, Penelitian, dan Pengembangan. 5, no. 1 (2020).

${ }^{18}$ Hyoscyamina, D. E., "Peran Keluarga dalam Membangun Karakter Anak," Jurnal Psikologi, 10 , no. 2, (2011): 144-152
} 
yang sama juga akan berlanjut pada lingkungan kehidupan yang lebih luas yakni di dalam kehidupan masyarakat luas di mana anak-anak nantinya hidup bermasyarakat, misalnya di sekolah dan kehidupan masyarakat pada umumnya. Pada masa pandemic Covid-19 saat ini, kebanyakan orang cenderung untuk egois, dan memikirkan keselamatan diri sendiri. Tatanan konsep yang tertanam dalam benak anak bisa jadi tidak seperti biasanya, di mana anak akan memiliki keegoisan sebagai akibat dari keegoisan orangtua selama masa pandemic diberlakukan. Oleh karena itu, anak perlu mendapatkan penjelasan yang cukup dari orangtua mengenai perilaku yang harus dilakukan selama pandemic berlangsung, dan perilaku setelah pandemic berakhir.

Keenam, fungsi ekonomi. Menurut Maslow, ada lima kebutuhan utama manusia, yaitu: kebutuhan fisiologis, kebutuhan keamanan dan keselamatan, kebutuhan sosial, kebutuhan penghargaan dan kebutuhan aktualisasi diri. ${ }^{19}$ Kebutuhan fisiologis merupakan bagian dari kebutuhan ekonomi. Pada umumnya kebutuhan fisiologis mencakup pememenuhan sandang/pakaian, pangan/makanan, papan/rumah, dan kebutuhan biologis seperti buang air besar, buang air kecil, bernafas, seks dan lain sebagainya. Kebutuhankebutuhan tersebut disebut sebagai kebutuhan paling dasar pada manusia. Khususnya yang terkait dengan usaha memenuhi kebutuhan ekonomi anggota keluarga, maka orang tua harus memastikan bahwa keluarga merupakan sarana yang paling potensial untuk pemenuhan kebutuhan ekonomi fisik dan materil. Terkait dengan hal tersebut, orang tua mempunyai tanggung jawab untuk mendidik keluarga agar memiliki mental rajin bekerja, hidup efisien, ekonomis dan rasional. Mental seperti itu harus dimulai dibentuk di rumah dan/atau di dalam keluarga. Penelitian yang dibuat oleh Benyamin dan Gratia memberikan gambaran lebih lanjut mengenai strategi pendidikan keluarga bagi anak yang menjadi korban kemiskinan. ${ }^{20}$ Pandemi Covid-19 menyebabkan pergeseran ekonomi baik secara makro maupun mikro. Sebagian orangtua bahkan terkena dampak ekonomi akibat Covid-19 ini, seperti terkena PHK, menurunnya omset bisnis, dan mulainya bekerja dari rumah. Dampak ekonomi ini dimungkinkan akan berdampak kepada anak. Sebagai contoh, ketika anak melihat bahwa orangtuanya menjadi pengangguran akibat PHK, maka dimungkinkan anak akan merasakan ketakutan akibat tidak tercukupinya kebutuhan yang biasanya dapat dicukupi dengan baik ketika orangtua masih aktif bekerja.

Ketujuh, fungsi rekreasi. Tantangan dan pergumulan hidup manusia semakin hari semakin kompleks. Secara otomatis, kondisi seperti itu terasa secara kuat di dalam setiap keluarga tanpa terkecuali. Itulah sebabnya keluarga harus memastikan terjadinya proses pendidikan rekreasi dalam keluarga. Para orang tua harus menciptakan dan memberikan suasana yang sangat gembira dalam lingkungan keluarganya. Dengan kata lain, keluarga harus menjadi lingkungan yang nyaman, menyenangkan, cerah, ceria, hangat, penuh kasih dan semangat. Karena itu, orang tua harus mengajarkan kepada anak-anak tentang nilai, manfaat, keterampilan bermain, bersenda gurau, berfantasi, mengunakan waktu untuk suatu kesenangan dan kegiatan kreatif. Dengan adanya pandemic Covid-19, guru cenderung

\footnotetext{
${ }^{19}$ H. A. Maslow, A Theory of Human Motivation (General Press, 2019)

${ }^{20}$ Benyamin, Mahendra, and Santosa, "Metode Pembelajaran Untuk Meningkatkan Prestasi Belajar Siswa Pada Mata Pelajaran Pendidikan Agama Kristen: Studi Meta Analisis."
} 
mengarahkan pembelajaran online yang salah satunya menggunakan model project based learning (PBL). Model ini diakui oleh orangtua memiliki keunggulan seperti terciptanya suasana rekreasi dalam pembelajaran, serta meningkatnya kreatifitas anak. Hal ini sesuai dengan penelitian yang dilakukan oleh Yunianta, Rusilowati, dan Rochmad ${ }^{21}$. Selain itu, selama masa pandemic covid-19 saat ini, kegiatan rekreasi menjadi terganggu, sehingga anak hanya merasakan berwisata dari rumah saja. Media utama untuk berekreasi dari rumah ini dilakukan melalui media komunikasi seperti HP dan laptop. Hal ini dapat berdampak pada kesehatan anak, maupun kecenderungan anak untuk kecanduang gadget. Hal inilah yang menjadi tantangan tersendiri bagi keluarga untuk mendidik anaknya dengan fungsi rekreasi yang tepat.

Berbagai teori maupun hasil-hasil penelitian tentang pendidikan dalam keluarga belum ada yang mengakomodir ketujuh fungsi tersebut sebagai satu kesatuan. Hal ini dikarenakan teori-teori mengenai peran keluarga dalam pendidikan dibangun oleh para ahli berdasarkan hasil kajian dalam kondisi normal. Hasil kajian yang dilakukan tentu berbeda dengan hasil penelitian ini, di mana kajian dalam penelitian ini dilakukan pada masa pandemi Covid-19.

Sebagaimana beberapa teori dan hasil penelitian yang telah dikutip, tampak bahwa studi-studi terdahulu lebih banyak berfokus pada satu komponen fungsi atau peran tertentu. Fungsi-fungsi atau peran-peran tertentu tersebut merupakan peran yang dilakukan oleh orangtua pada masa normal (tidak dalam masa pandemi Covid-19 seperti saat ini). Oleh karena itu, dapat dikatakan bahwa hasil penelitian ini mengandung kebaharuan berupa pengajuan 7 fungsi peran keluarga dalam pendidikan anak. Ketujuh peran tersebut tampak sangat strategis dan perlu dilakukan dengan sebaik-baiknya oleh keluarga dalam rangka membentuk anak untuk siap terjun dalam kehidupan yang sebenarnya, khususnya dalam masa pandemi Covid-19. Karena peran tersebut ditemukan berdasarkan kajian ketika terjadi pandemi Covid-19 maka, dimungkinkan ketujuh peran ini tidak akan relevan apabila diterapkan pada masa selain pandemi Covid-19.

\section{KESIMPULAN}

Pandemi Covid-19 menyebabkan perubahan pola hidup masyarakat saat ini. Kehidupan baru yang diwarnai dengan social distancing, larangan jabat tangan, dan sebagainya dapat dimaknai oleh anak sebagai hal yang biasa terjadi, dan mungkin akan dilakukan seterusnya hingga dewasa. Konsep yang salah inilah yang perlu disikapi oleh orangtua. Hasil penelitian menunjukkan bahwa terdapat 7 peran utama keluarga dalam pendidikan anak, yaitu: (1) Fungsi keimanan; (2) Fungsi edukatif; (3) Fungsi sosialisasi; (4) Fungsi proteksi atau perlindungan; (5) Fungsi afeksi; (6) Fungsi ekonomi; (7) Fungsi rekreasi. Ketujuh peran tersebut muncul ketika penelitian dilakukan pada masa pandemi Covid-19. Oleh karena itu, peran tersebut dimungkinkan akan berbeda apabila penelitian

${ }^{21}$ Yunianta, T. N. H., Rochmad, A., Rusilowati. Kemampuan Berpikir Kreatif Siswa Pada Implementasi Project Based Learning Dengan Peer and Self-Assessment Untuk Materi Segiempat Kelas VII SMPN RSBI 1 Juwana di Kabupaten Pati. In Prosiding Seminar Nasional Matematika dan Pendidikan Matematika 2012. Yogyakarta 
dilakukan tidak pada masa pandemi Covid-19 maupun saat-saat yang lain, seperti masa new normal dan masa terjadinya bencana dalam bentuk yang lain.

Berdasarkan simpulan tersebut, disarankan kepada orangtua untuk mengubah pola didikan anaknya ke pola versi pandemi Covid-19 seperti telah dihasilkan dalam penelitian ini. Orangtua perlu melakukan adaptasi atau penyesuaian diri dengan kondisi baru, sehingga orangtua dapat menjalankan peran-perannya dengan baik, seperti telah dihasilkan dalam penelitian ini. Selain itu, disarankan kepada peneliti selanjutnya untuk mengkaji mengenai peran keluarga dalam pendidikan anak pada kondisi-kondisi yang lain (kondisi selain pada masa pandemic Covid-19), seperti kondisi pada pembelajaran di era new normal maupun ketika bencana lain terjadi. Dengan demikian akan diperoleh perbedaan antara hasil penelitian ini dengan hasil penelitian yang dilakukan pada masa selain pandemic Covid-19. Perbedaan-perbedaan tersebut akan menjadi kajian yang menarik untuk diperbandingkan, di mana orangtua dituntut untuk fleksibel, dan mampu mendidik anak pada berbagai kondisi yang mungkin dapat terjadi pada masa yang akan datang.

\section{REFERENSI}

Amtiran, Abdon. "Pandemi Covid-19 Dan Implikasinya Terhadap Polarisasi Mazhab Teologi Di Indonesia." MAGNUM OPUS: Jurnal Teologi dan Kepemimpinan Kristen 1, no. 2 (2020): 64-71.

Benyamin, P. I., Gratia, Y. P. 2019. Pengembangan Model Pendidikan Agama Kristen Bagi Anak Korban Kemiskinan. Jurnal Ecodunamika. 3 (1)

Benyamin, Prislika issak, Yogi Mahendra, and Donald Samuel Slamet Santosa. "Metode Pembelajaran Untuk Meningkatkan Prestasi Belajar Siswa Pada Mata Pelajaran Pendidikan Agama Kristen: Studi Meta Analisis.” SOTIRIA (Jurnal Teologi dan Pelayanan Kristiani) 3, no. 1 (2020): 25-35. http://sttpaulusmedan.ac.id/ejournal/index.php/sotiria/article/view/17.

Berutu, Irwanto, and Harls Evan R Siahaan. "Menerapkan Kelompok Sel Virtual Di Masa Pandemi Covid-19." SOTIRIA (Jurnal Theologia dan Pendidikan Agama Kristen) 3, no. 1 (2020): 53-65.

Darmadi, H. 2019. Pengantar Pendidikan Era Globalisasi: Konsep Dasar, Teori, Strategi dan Implementasi dalam Pendidikan Globalisasi. An1mage.

Endraswara, S. 2006. Metode, Teori, Teknik Penelitian Kebudayaan: Ideologi, Epistemologi, dan Aplikasi. Yogyakarta: Pustaka Widyatama

Fowler, J. W. 1995. Stages of Faith: The Psychology of Human Development. Harper Collins

Hyoscyamina, D. E. 2011. Peran Keluarga dalam Membangun Karakter Anak. Jurnal Psikologi. 10 (2) 144-152

Machmudah, Supriyono, Rasyad, A. 2020. Perilaku Orangtua Menumbuhkan Kemandirian Sosial di Sekolah Melalui Proteksi Orangtua, Kelekatan Ibu dan Pola Tidur Anak. Jurnal Pendidikan: Teori, Penelitian, dan Pengembangan. 5 (1)

Maslow. H. A. 2019. A Theory of Human Motivation. General Press

Miles, M. B., Huberman, A. M., Saldana, J. 2014. Qualitative Data Analysis: A Methods Sourcebook. Sage Publication.

Dwiraharjo, Susanto. "Konstruksi Teologis Gereja Digital: Sebuah Refleksi Biblis Ibadah Online Di Masa Pandemi Covid-19." EPIGRAPHE: Jurnal Teologi dan Pelayanan Kristiani 4, no. 1 (2020): 1-17. 
Purba, Asmat. "Tanggung Jawab Orang Tua Kristen Dalam Mendidikan Anak Menyikapi Pandemi Covid-19.” EPIGRAPHE: Jurnal Teologi dan Pelayanan Kristiani 4, no. 1 (2020): 86-100.

http://www.stttorsina.ac.id/jurnal/index.php/epigraphe/article/view/148.

Saryono. Metode Penelitian Kualitatif, Bandung: Alfabeta, 2010

Siahaan, Harls Evan Rianto. "Hikmat Sebagai Implikasi Pendidikan Kristiani Dalam Keluarga: Refleksi 1 Raja-Raja 3:1-15.” DUNAMIS (Jurnal Teologi dan Pendidikan Kristiani) Vol 1, no. 1 (2016): 15-30. www.sttintheos.ac.id/ejournal/index.php/dunamis.

Sihotang, F. H., Santosa, D. S. S. Pengaruh Prestasi Belajar, Penguasaan Teknologi Informasi dan Pengalaman Organisasi Terhadap Kesiapan Kerja. Jurnal Ecodunamika. 2, no. 1 (2019)

Sijabat, B. S. Membesarkan Anak Dengan Kreatif, Yogyakarta: Andi Offset, 2008

Susanta, Yohanes Krismantyo. "Tradisi Pendidikan Iman Anak Dalam Perjanjian Lama." BIA': Jurnal Teologi dan Pendidikan Kristen Kontekstual 2, no. 2 (2019): 139-150.

Widjaja, Fransiskus Irwan, Candra Gunawan Marisi, T. Mangiring Tua Togatorop, and Handreas Hartono. "Menstimulasi Praktik Gereja Rumah Di Tengah Pandemi Covid19.” Kurios (Jurnal Teologi dan Pendidikan Agama Kristen) 6, no. 1 (2020): 127-139. http://www.sttpb.ac.id/e-journal/index.php/kurios/article/view/166.

Yamin, M. Menggugat Pendidikan Indonesia: Belajar dari Paulo Freire dan Ki Hajar Dewantara. Yogyakarta: Ar Ruzz Media, 2009.

Yunianta, T. N. H., Rochmad, A., Rusilowati. Kemampuan Berpikir Kreatif Siswa Pada Implementasi Project Based Learning Dengan Peer and Self-Assessment Untuk Materi Segiempat Kelas VII SMPN RSBI 1 Juwana di Kabupaten Pati. In Prosiding Seminar Nasional Matematika dan Pendidikan Matematika 2012. Yogyakarta 